\title{
The Impact of School Resource Investment on Student Performance: A Meta-analysis Based on Chinese Literature
}

\author{
Yahui Tian, Jijun Yao \\ Nanjing Normal University, Nanjing 210024, China
}

\begin{abstract}
Using meta-analysis, this study analyzes a total of 20 effects on 11 articles on the impact of Chinese school resource investment on student performance. We found that: 1) the overall impact of school resources on student performance is significant (effect amount is 0.093, p $=0.001)$; 2) compared with the effect of school human resources investment and financial resources investment, human resources are superior, the effect amounts are $0.121(p<0.01), 0.120(p=0.014)$; the effect of material resource is the lowest, but the impact is also very important with an effect amount of $0.099(p=0.009)$; 3) in human resource investment, teacher experience, teacher education, teacher qualifications, teacher training, teacher titles, and student-teacher ratios all have a positive and significant impact on student performance. Among the material resources, computer networking rates, average student fixed assets, average classroom and school areas affect students' achievements significantly; 4) from a disciplinary perspective, the impact of school resource investment on Chinese language and mathematics is more significant, and from a regional perspective, the impact on central and western regions is more significant. We suggest based on our findings as: First, increase investment in school resources, especially financial resources and investment in schools in the western region; Second, pay attention to the input and allocation of teachers' resources, especially to improve the shortage of small-scale high-quality teachers in rural areas; Third, keep pace with the times and improve the allocation of physical conditions in schools.
\end{abstract}




\section{Question}

7 HE findings of the Coleman Report show that school resource investment does not have a significant impact on student performance (Coleman, et al., 1966).

1 This finding has sparked a lot of research and debate about the relationship between school resources and student achievement. Since then, the use of educational production functions to study the relationship between school resources and student performance has become a hot topic in related fields. But until today, no consensus has been reached on such studies. Two of the most representative views are the related arguments of Hanushek and Hedges. Hanushek's series of studies have not found direct evidence that school resource investment significantly affects student achievement, and therefore believes that education policy cannot be simply thought of when it comes to school resource investment (Hanushek, 1989; Hanushek, 1995; Hanushek, 1997). But Hedges and others have criticized and questioned Hanushek's research methods, research data, and research results. They used meta-analysis to re-analyze the data used by Hanushek in 1989, and obtained the opposite of Hanushek's conclusion. The metaanalysis results show that most of the school's resources have a significant impact on student performance, including the average student expenditure; teachers' quality (teacher education, experience, and ability) has a positive and significant positive impact on student performance, while school size and class size have significant negative correlations with student performance (Hedges, et al., 1994). A series of research by Hedges et al. has re-ignited people's emphasis on school resource investment. However, due to the complexity of the relationship between school investment and student achievement, a large number of subsequent studies have also found that: due to the country's sentiment, research data, relevant research conclusions are not completely consistent for reasons such as the setting of the model and the selection of variables. For example, Fuller analyzed the relationship between school resources and student performance in the Third World, and found that in developing countries, school factors are the main cause of differences in student performance (Fuller, 1987). Hattie used metaanalysis to analyze more than 800 factors affecting student academic achievement, including comprehensive analysis of six types of factors: individual students, families, schools, teachers, courses and teaching, and found that school resources have a positive and significant impact on student performance. Among them, the influence of teachers is the most significant and has been hailed as the "Holy Grail of Teaching" by Hattie (Hattie, 2015).

\footnotetext{
About the Author: Yahui Tian, B.A., Master's Candidate, School of Education Science, Nanjing Normal University, Nanjing 210024, China. E-mail: 1358622935@qq.com.
}

Correspondence to: Jijun Yao, Ph.D., Professor, School of Education Science, Nanjing Normal University, Nanjing 210024, China. E-mail: yaojijun_njnu@163.com.

Funding: This study was supported by the Jiangsu Province Superior Discipline Construction Project Funding Project (PAPD).

Conflict of Interests: None. 
Research from China on the relationship between school resource investment and student performance started late. At the end of the 1990s, Jiang (2000) studied the rural bases through multivariate analysis of variance and related analysis, using statistics on education expenditure and education in 328 counties in nine provinces of East, Central and West China in 1990 The relationship between education investment and student achievement (Jiang, 2000). This study opened the prelude to China's research on school resources and student performance. Especially since 2006, more and more related studies have been conducted, but so far, no uniform conclusion has been reached. Some scholars have found that school resources, such as teacher age, student-teacher ratio, average number of students, average school area, average classroom area, average student education expenses, average student career expenses, and average student public expenses, etc., have significant effects on student performance (Hu, 2007), but some scholars have found that some indicators have little or no correlation with student performance. For example, Zhao found that the average teaching age of teachers will negatively affect student performance (Zhao, 2013).

It can be seen that in the past 5 decades, there has been an endless stream of research on school resources and student performance, but so far, relevant research has not yet reached a clear and consistent conclusion. However, such studies have found that there are some correlations between school resources and student performance, and this relationship mainly exists in the three areas of human, finance, and material. Compared with foreign studies, because Chinese school-related data is more difficult to obtain, there are fewer empirical studies on the relationship between school resources and student performance. The reason did not reach a consensus conclusion. This leads to the lack of the best evidence of robustness in improving the process and efficiency of school resource investment, which affects the scientificity and pertinence of decisionmaking. Considering that China is a large and rapidly developing country, synthesizing the evidence on the relationship between Chinese school resource investment and school output will help us understand the relationship between the two in a more detailed and comprehensive manner, and it will also help us Provide "best evidence" from China for theoretical research in this area. Such research can not only have a more accurate understanding of the benefits of human, financial, and material inputs, but also have important reference values for improving future education finances, school-level education resource allocation, and funding input. Because the conclusions of the existing empirical studies are not consistent, the most suitable analysis methods in this process are meta-analysis and systematic evaluation. But so far, the meta-analysis or systematic review of China in this field is almost blank. Therefore, no matter from the theoretical research or policy improvement, it is urgent to give solid evidence for the following issues: (1) What is the relationship between school resource investment and student achievement? (2) Which of the human, material and financial resources of school resources has a greater impact on student performance?

\section{Definition}




\section{School Resources}

School resources refer to the sum of resources occupied, used and consumed to maintain school education and teaching activities. School resources are usually divided into three dimensions: human, material and financial resources. Specifically, the school's human resources, that is, the school teacher team and students, of which the teacher team includes full-time teachers and non-full-time teachers, this study mainly discusses the impact of full-time teachers on student performance. Material resources refer to tangible assets and low-value consumables invested in schools, such as school buildings, land, books, materials, and other fixed assets. Financial resources usually refer to the monetary performance of human and material resources (Hanushek, 1997).

In the selection of indicators of various dimensions, we draw on the practice of scholars at home and abroad. Teacher qualification, teacher education, teacher teaching age, teacher training, teacher-student ratio and teacher title were selected as the indicators of school human resources input. The average school area of the students, the average number of school books, the average classroom area of the students, the average building area of the students 'school, the average number of students' computers, and the computer network rate are taken as the indicators of the school's material resources. The average public funding of students is used as an indicator of the financial resources of the school (see Table 1 for the meaning of each indicator).

\section{Academic Performance}

Students' academic performance is the primary concern of parents and an important indicator for measuring the effectiveness of school education ( $\mathrm{Li} \&$ Zhang, 2018). It also predicts the level of education that students may receive in the future and the benefits in the labor market (Lipsey \& Wilson, 2001). This article measures the impact of school resource investment on student performance, including both the student's overall academic performance and various subjects (such as mathematics, Chinese language, English, science, etc.).

\section{Research Design}

\section{Analysis Methods and Tools}

The analysis method used in this study is meta-analysis, which is a literature analysis method combining qualitative and quantitative analysis methods (Xia, 2005), that is, a method of statistical analysis of a single research result by synthesizing existing related research findings ( $\mathrm{Gu} \& \mathrm{Hu}, 2018$; Glass, 1976). Unlike traditional literature analysis, it extracts relevant information from existing research, such as sample size, standard deviation, correlation coefficient, etc., calculates the effect amount, and judges the degree and direction of the impact based on the size and direction of the effect amount. This avoids the subjectivity and non-repeatability of traditional literature analysis and helps people to obtain "best evidence" (Gu \& Hu, 2018). 
The effect size refers to the comparison between different studies by standardizing the results of each study. Different types of meta-analysis have different effect sizes (Lipsey \& Wilson, 2001). There are two types of commonly used effect quantities. One is the standard difference type, such as Cohen'd, Hedges'g, and Glass $\Delta$ (Lu, et al., 2011). Because most of the current meta-analysis are based on experimental studies to investigate the effect of an experimental intervention on the experimental results, $\mathrm{d}$ or $\mathrm{g}$ are mostly used for the effect amount. The other is the correlation effect, which mainly includes $r_{\text {pearson }}$ and $r_{p b}$ (Ferguson, 2009). Most of this type of effect is suitable for univariate correlation analysis and analysis of variance. As the research on the relationship between school resource investment and student performance is mostly based on multiple regression analysis or multi-level linear models, these types of effect quantities are not applicable. For this reason, in many such studies, standardized regression coefficients are used as the effect size (Mark et al., 2001). When Hedges et al. analyzed the impact of school resource investment on student performance, considering that in all studies, input variables and output variables are usually not measured on the same scale, the partial regression coefficients obtained cannot be directly calculated or compared. Therefore, standard regression coefficients are used as effect quantities for combination and comparison (Greenwald et al., 1996). The standard regression coefficient measures the change in the output variable caused by a standard deviation change in the input variable.

Since not all studies have reported standardized regression coefficients. Therefore, in the following research, we first refer to the calculation formula of Nieminen et al. (Nieminen et al.,2013).to convert the non-standardized regression coefficients into standardized coefficients; then use Comprehensive Meta Analysis 2.0 (CMA 2.0) software developed by Biostat to calculate the effect amount Test heterogeneity, perform sensitivity analysis, and test for publication bias. In addition, in specific calculations, in order to ensure the principle of sample independence, using documents as the unit, first calculate the overall effect amount of each document and the corresponding effect amount of human, material and financial resources; then combine the overall effect amounts of all documents, manpower input effect amount, material input effect amount, and financial input effect amount.

\section{Collection and Selection}

First, determine the inclusion criteria for the literature. The inclusion criteria need to be accurately framed, including the type of document, year, language, research method used, and whether the effect size can be calculated. The rest depends on the specific research purpose. This process should be avoided as much as possible based on the personal preference of the researcher, and its criteria need to be determined more based on the research purpose, research content, literature characteristics and statistical requirements. The criteria for document inclusion need to include at least the following basic elements: the salient features of the document to be included, the research object, the key variables, the study design, the cultural and linguistic range, the time range, and the 
type of document. Based on the research purpose and the basic elements that the inclusion criteria should include, this study has developed six criteria to screen the literature:

1. The study was published between 1990 and 2018. The language used is Chinese and/or English, and the type of literature is not limited.

2. The research content is the impact of school running conditions on the academic performance of basic education students. The school running conditions include human, material and financial resources or one of them.

3. The research objects only include research from ordinary middle and elementary schools in China, excluding pre-school education, vocational education, and higher education.

4. The research must present clear, clear and complete statistical data results. Statistical information such as the mean, standard deviation, sample size or $\mathrm{t}$ value, $F$ value should be reported to ensure that the effect amount can be calculated.

5. Research methods are limited to empirical research. Including (quasi) experimental research and research based on experimental research ideas (such as research using RDD, DID, PSM methods), and research using multilayer linear model (HLM), structural equations, correlation analysis and other methods.

6. The dependent variable of the research model is the student's academic performance, including the total score and the results of various subjects such as Chinese language, mathematics, and English.

Secondly, the literature was searched according to the criteria. The keywords we searched are "school resources", "school conditions", "academic performance", "academic performance", "academic achievements", "teacher resources", "teacher human capital", "school investment", "Financial investment in education", "education production function", etc. The search database includes educational databases such as CNKI, CQVIP, Wanfang Data, Baidu Academic, Google Academic Mirror, EBSCOhost, JSTOR Retrospective Database, etc., and obtained more relevant literature through the "snowball" method. A total of 161,897 articles were retrieved through keyword searches. By contrasting with the inclusion criteria, first of all, screening is performed according to the title of the document to exclude studies that do not meet the requirements. After screening based on the keywords, the title and abstract of the article are read to further exclude the research that does not meet the requirements. Finally, the remaining documents are read in full. A total of 11 studies were included, including 20 effect sizes. The details of the literature search in each database are as follows (Figure 1).

\section{Extract and Encode Bibliographic Information}

The information included in the extracted literature includes author, publication year, research grade, research area, data type, research method, independent variable selection, dependent variable selection, sample information (including sample size, and demographic characteristics of the sample) and average, $\mathrm{T}$ value, standard deviation and 


\section{Table 1.The Meaning of Each Indicator.}

\begin{tabular}{|c|c|}
\hline $\begin{array}{l}\text { School } \\
\text { Resources } \\
\end{array}$ & Indicator Variables and Meanings \\
\hline \multirow{6}{*}{$\begin{array}{l}\text { Human } \\
\text { Resources }\end{array}$} & $\begin{array}{l}\text { Teacher qualification: whether there is a teacher qualification certificate, the } \\
\text { proportion of teachers qualification certificate }\end{array}$ \\
\hline & $\begin{array}{l}\text { Teacher age: that is, using the number of years of teaching as a proxy for } \\
\text { teacher experience }\end{array}$ \\
\hline & Teacher's education: the education level of the teacher \\
\hline & Teacher training: the total training time for teachers \\
\hline & Teacher-student ratio: number of full-time teachers / number of students \\
\hline & Teacher titles: namely junior titles, intermediate titles, senior titles \\
\hline \multirow{6}{*}{$\begin{array}{l}\text { Material } \\
\text { Resources }\end{array}$} & $\begin{array}{l}\text { Students are school area; the ratio of the number of students and the } \\
\text { school covers }\end{array}$ \\
\hline & $\begin{array}{l}\text { Students are school drawing book ratio of the number of copies :: books } \\
\text { and school books count the number of students }\end{array}$ \\
\hline & $\begin{array}{l}\text { Classroom area per student: Ratio of school classroom area to student } \\
\text { population }\end{array}$ \\
\hline & $\begin{array}{l}\text { School building area per student: Ratio of school building area to student } \\
\text { number }\end{array}$ \\
\hline & $\begin{array}{l}\text { Number of computers per student: Ratio of computers to students in } \\
\text { schools }\end{array}$ \\
\hline & $\begin{array}{l}\text { Computer networking rate: ratio of the number of computers connected to } \\
\text { the school to the total number of computers owned by the school }\end{array}$ \\
\hline $\begin{array}{l}\text { Financial } \\
\text { Resources }\end{array}$ & Public Funds per student: Ratio of public funds to number of students \\
\hline
\end{tabular}

other information to calculate the effect amount. The encoding rules used are as follows (Table 2).

1. Input Variable: In human resources, the student-teacher ratio is coded as $\mathrm{P} / \mathrm{T}$; the teacher-student ratio is coded as T/P; the teacher qualification code is TEq; the teacher experience code is TExp; the teacher education code is Ted; the teacher the title code is TEt, and the teacher training code is TEc. In material resources, the number of students per book is coded as PSB; the number of students per computer is coded as PSC; the computer network rate is coded as $\mathrm{RC}$; the number of students per year of fixed assets is coded as PCFA; the average construction area per student is GFPS. Among the financial resources, the public expenditure code per student is PPE.

2. Output Variable: The total score is coded as Total, the math score is coded as Math, the language score is coded as Chinese, the language reading score is Reading, the English score is coded as English, the science score is coded as Science, and other scores are coded as U.

3. Grade: Elementary school code is P, middle school code is S, and high school code is $\mathrm{H}$. 


\begin{tabular}{|c|c|c|c|c|c|c|c|c|c|}
\hline$\#$ & Author & IV & OV & RS & SA & SS & RD & LT & DT \\
\hline 1 & Liang Huang (2018) & $\begin{array}{l}\text { PSC, RC, TEq, } \\
\text { Ted }\end{array}$ & $\begin{array}{l}\text { Math, Read- } \\
\text { ing, Science }\end{array}$ & $\mathrm{S}$ & $\mathrm{E}$ & HLM & $\mathrm{FL}$ & $J$ & G \\
\hline 2 & $\begin{array}{l}\text { Xiangyun Li, Ping } \\
\text { Wei (2014) }\end{array}$ & $\begin{array}{l}\text { T/P, TEt, PSB , } \\
\text { PCFA, PPE }\end{array}$ & $\begin{array}{l}\text { Chinese, } \\
\text { Math }\end{array}$ & $\mathrm{P}$ & M & HLM & $\mathrm{FL}$ & $J$ & I \\
\hline 3 & Xue Xia (2009) & TEt & Math & $P$ & W & HLM & $\mathrm{FL}$ & $\begin{array}{l}\text { non- } \\
\mathrm{J}\end{array}$ & $\mathrm{C}$ \\
\hline 4 & $\begin{array}{l}\text { Yuhong Du, Yongmei } \\
\text { Hu (2009) }\end{array}$ & $\begin{array}{l}\text { PSB , SAFA, } \\
\text { TEq, P/T } \\
\text { TExp, PPE }\end{array}$ & $\begin{array}{l}\text { Chinese, } \\
\text { Math }\end{array}$ & $\mathrm{S}$ & W & OLS & QL & $J$ & C \\
\hline 5 & $\begin{array}{l}\text { Haiping Xue, } \\
\text { Weifang Min (2008) }\end{array}$ & $\begin{array}{l}\text { PPE, Ted, } \\
\text { TEq, TEt, TEc, } \\
\text { TExp }\end{array}$ & $\begin{array}{l}\text { Chinese, } \\
\text { Math }\end{array}$ & $\mathrm{S}$ & EM & HLM & QL & $J$ & C \\
\hline 6 & Yongmei Hu (2007) & $\begin{array}{l}\text { PSCA, PSB } \\
\text { SAFA, P/T } \\
\text { TEq, PPE }\end{array}$ & $\begin{array}{l}\text { Chinese, } \\
\text { Math }\end{array}$ & $\begin{array}{l}\mathrm{P}, \\
\mathrm{S}\end{array}$ & W & HLM & QL & $\begin{array}{l}\text { non- } \\
\mathrm{J}\end{array}$ & C \\
\hline 7 & $\begin{array}{l}\text { Xuehui An, Emily } \\
\text { Hannum, Tanja Sar- } \\
\text { gent (2008) }\end{array}$ & TExp, Ted & Total & $\mathrm{P}$ & $\mathrm{N}$ & HLM & QL & $J$ & C \\
\hline 8 & $\begin{array}{l}\text { Jennifer Adams } \\
(2012)\end{array}$ & TExp, TEt, Ted & Math & $\mathrm{P}$ & W & HLM & $\mathrm{FL}$ & $J$ & C \\
\hline 9 & Qiuyi Weng (2009) & SAFA, GFPS, & Total & $\mathrm{S}$ & EW & OLS & $\mathrm{FL}$ & J & $\mathrm{C}$ \\
\hline 10 & $\begin{array}{l}\text { Yanqing Ding, } \\
\text { Haiping Xue (2008) }\end{array}$ & $\begin{array}{l}\text { PPE, Ted, } \\
\text { TEq, T/P }\end{array}$ & Total & $\mathrm{H}$ & W & HLM & QL & $J$ & C \\
\hline 11 & $\begin{array}{l}\text { Haiping Xue, Rong } \\
\text { Wang (2009) }\end{array}$ & $\begin{array}{l}\text { PPE, Ted, } \\
\text { TEq, TEt, TEc, } \\
\text { TExp, P/T }\end{array}$ & Math & $\mathrm{P}$ & EM & HLM & QL & J & C \\
\hline
\end{tabular}

4. Study Area (Area): the national code is N, the eastern code is E, the central code is $\mathrm{M}$, the western code is $\mathrm{W}$, the eastern and central and central and eastern codes are both EM, and the central and western and central and western codes are MW.

5. Method: The multivariate linear model is OLS, and the multilayer linear model is HLM.

6. Study Design: With reference to the practice of Greenwald et al., The research design is divided into longitudinal studies (coded as L) and quasilongitudinal studies (coded as L) according to whether the study includes front-to-back testing, whether to control student IQ, and previous performance. Coded as QL and Non-Longitudinal Studies (FL). In this sample, only quasi-longitudinal and non-longitudinal studies are included.

7. Literature Type (Lt): Articles published in journals are coded as $\mathrm{J}$, and non-journal literatures are coded as non-J.

8. Data Sources: According to the data sources, the data is divided into three categories: first, international data, such as PISA, authoritative data with global significance, coded as G; followed by some important issues in 
China There are semi-official and authoritative data in China. Such data is usually large-scale survey data of multi-agency cooperation across provinces. The measurement tools used by them are authoritative institutions or experts to develop standardized test papers. The relevant questionnaires have also been repeatedly verified and coded as $\mathrm{C}$; once again, the data obtained by researchers and their research groups through self-made questionnaires, and the reliability and representativeness of the results Sex is worse than the former two, coded as I.

In many previous meta-analysis studies, the sample size, randomness of sampling, etc. are often coded and discussed. However, in our research, all samples are large samples, and the sampling methods are generally consistent, so we did not separately encode and analyze such information.

\section{Analysis Framework}

We first analyzed the overall impact of school resources on student performance, and then separately analyzed the impact of student human resources, material resources and financial resources on student performance, thereby determining which aspects of investment are more effective. On this basis, we further analyzed the impact of human resources and material resources on student performance. Student grades include student grades and total student grades. At the same time, the introduction of moderating variables, that is, the impact of different disciplines, different academic periods, different research areas, different research methods, different research designs, literature types and data types on student performance, in order to test the sources of heterogeneity between different studies, and then comprehensively evaluate The impact of school resource investment on student performance (see Figure 2 for the analysis framework). According to the steps of the meta-analysis, the quality of the included literature should be evaluated. However, in most cases, such quality evaluation standards are mainly applicable to the literature of experimental research, from whether the experimental design and process of the included literature are scientifically and rationally evaluated (Valentine \& Cooper, 2003). Such criteria are not suitable for this study. Because the documents we included are all officially published academic papers, which have undergone strict peer review, the research process is rigorous, and the conclusions are robust and reliable, the included documents have high quality and can meet the requirements of meta-analysis.

\section{Results}

\section{Heterogeneity Test and Model Selection}

In order to accurately examine the impact of school resource investment on student performance, a heterogeneity test was first performed. Tests for heterogeneity refer to whether different studies have heterogeneity and what causes heterogeneity. It is also called tests for homogeneity or homogeneity test. With reference to the results of heter- 


\section{Figure 1. Database Retrieval Flowchart.}

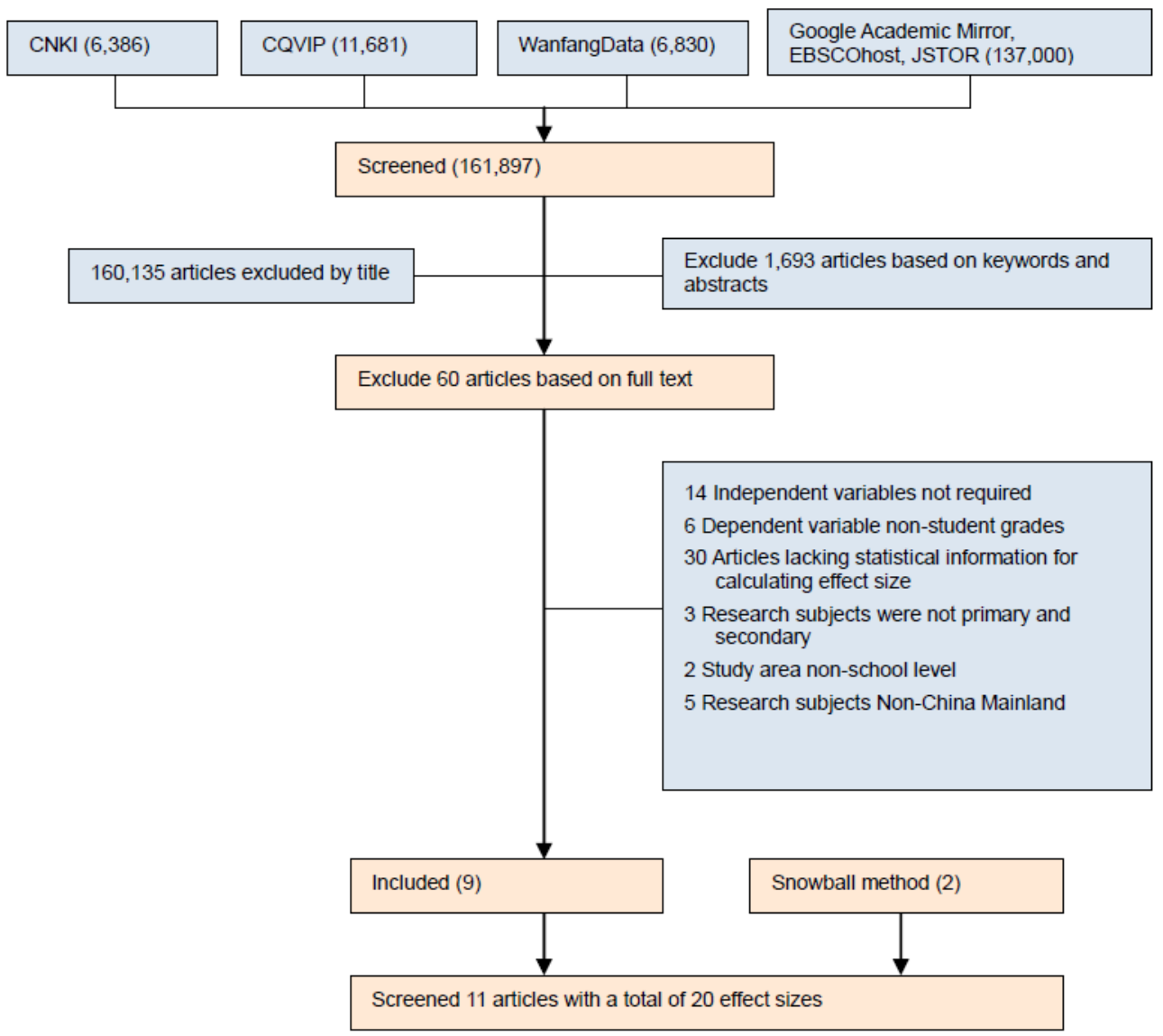

ogeneity analysis, a suitable statistical model is selected (Rücker, et al., 2008; Xia, 2005). If the test result is not significant ( $p>0.05$ ), it indicates that the studies are homogeneous, and a fixed effect model is selected; if the test result is significant $(\mathrm{p}<0.05)$, it indicates that there is heterogeneity between different studies. If there is heterogeneity, there are usually two processing methods. One is to use subgroup analysis and sensitivity analysis to eliminate heterogeneity processing methods such as extreme values or statistics with opposite directions, and then make it homogeneous using a fixed effects model (Xia, 2005); another method is to use a random effects model. However, Borenstein et al. proposed that the choice of analysis model should also be based on the source of heterogeneity. If the heterogeneity originates only from sampling errors, a fixed-effect model is selected. If it is assumed that in addition to sampling errors, heterogeneity also comes from factors such as study design and sample characteristics, a random effect model is selected (Borenstein, et al., 2009). 


\section{Figure 2. Analysis Framework Diagram.}

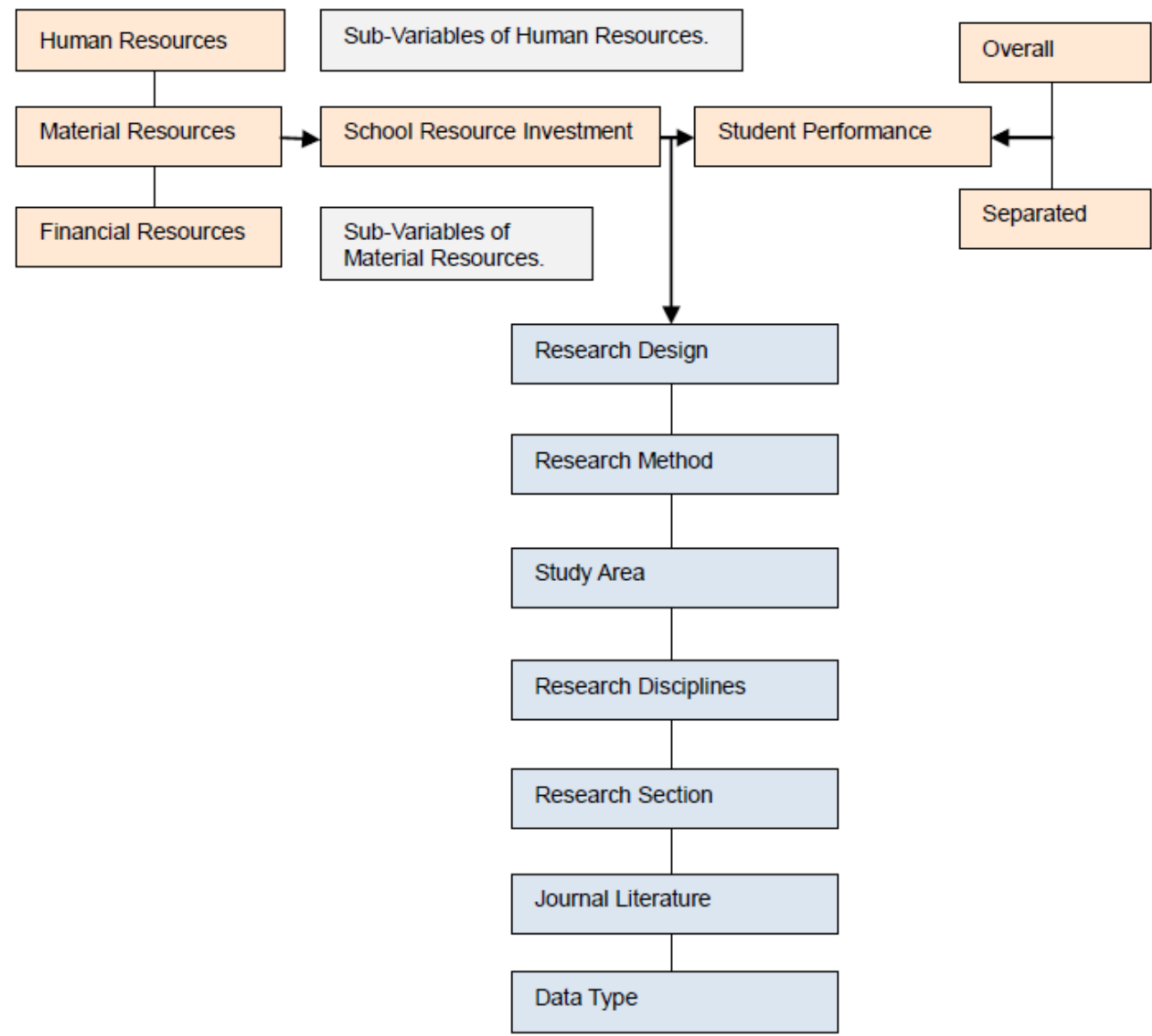

In the heterogeneity test of the overall impact of school resource investment on student performance, $\mathrm{Q}=674.236(\mathrm{p}<0.001)$ indicates that there is heterogeneity between the samples, and $\mathrm{I} 2=97.182$, indicating that about $97 \%$ of the variation comes from the difference between the effect values. Only $3 \%$ of the variation was due to sampling errors, so a random effects model was used for analysis. The test of the heterogeneity of the impact of school human, material and financial resources on student performance also shows that there are differences between different studies, and the variation mainly comes from factors other than errors, so a random effect model is also adopted.

\section{The Overall Impact of School Resource investment on Student Performance}


In the analysis of the results, referring to the practice of Greenwald et al., The effect size (Table 3) obtained was analyzed according to the standard regression coefficient, and the influence of this variable on student performance was analyzed (2009). The overall impact of school resource investment on student performance is shown in Table 4. The effect amount $\mathrm{ES}=0.093$ ( $\mathrm{p}=0.001$ ), which is equivalent to a standard regression coefficient of 0.093 . That is, an increase of one standard deviation in school resource investment will increase student performance by 0.093 of the standard deviation. This effect is very significant. Increasing investment in school resources will have a large impact on student performance, a result that is consistent with the conclusions of Hedges et al. (1994) and Hattie (2015).

\section{The Impact of School Personnel, Finance, and Material Inputs on Student Performance}

According to the results in Table 4, it can be seen that the input of school human resources has the greatest impact on student performance, with an effect amount of 0.121 ( $\mathrm{p}<0.001$ ), that is, an increase of one standard deviation in school human resource investment will increase student performance by 0.121 standard deviation, which is quite large Impact. The impact of financial resources investment is equivalent to that of human resources, with an effect size of $0.120(\mathrm{p}=0.014)$. The last is the impact of the school's material resource investment, with an effect amount of $0.099(p=0.009)$, which is less than the impact of financial and human resources, but it is sufficient to have an important impact on student performance.

Use subgroup analysis to explore the impact of human resource variables on student performance (see Table 5 for results). Since the teacher-student ratio and the student-teacher ratio are inverse relations to each other and cannot be simply merged, referring to the practice of Hedges et al., The effect magnitudes of the teacher-student ratio and the student-teacher ratio are calculated separately. The results in Table 5 show that in human resources, teacher experience, teacher training, teacher education, teacher titles, teacher qualifications, and student-teacher ratio all significantly affect student performance, and the effect range is [0.101, 0.185]. The results of this study are consistent with Hedges' report (Hedges, et al., 1994). However, the results show that the teacher-student ratio has no significant effect on student performance. This result may be because only three teachers-student ratios were used in the collected samples, so this result needs to be treated with caution.

Similar to human resources, subgroup analysis of the input effect of each variable of material resources was used (Table 6). However, unlike the results of various human resources variables, among the material resources, only the computer networking rate, the average fixed assets per student, the classroom area per student, and the school area per student significantly affect student performance and the effect range is [0.032, 0.222], but the number of students per computer, building area per student, and number of books per student did not significantly affect student performance. However, it should also be noted that the sample size of each variable in the material resources is 
Table 3. Effect Amount Report.

\begin{tabular}{|c|c|c|c|c|c|}
\hline \multirow[b]{2}{*}{ \# Author } & \multirow{2}{*}{$\begin{array}{l}\text { Output } \\
\text { Variable }\end{array}$} & \multicolumn{4}{|c|}{ Effect Size } \\
\hline & & Overall & $\begin{array}{l}\text { Human } \\
\text { Resources }\end{array}$ & $\begin{array}{l}\text { e-Material } \\
\text { Resources }\end{array}$ & $\begin{array}{l}\text { Financial } \\
\text { Resources }\end{array}$ \\
\hline 1 Liang Huang (2018a) & Math & 0.021 & 0.131 & 0.008 & l \\
\hline 2 Liang Huang (2018b) & Reading & 0.009 & 0.1 & 0.002 & 1 \\
\hline 3 Liang Huang (2018c) & Science & 0.023 & 0.117 & 0.019 & 1 \\
\hline 4 Xiangyun Li, Ping Wei (2014a) & Chinese & 0.243 & 0.441 & -3.512 & 0.242 \\
\hline 5 Xiangyun Li, Ping Wei (2014b) & Math & 0.121 & 0.064 & 0.05 & 0.181 \\
\hline 6 Xue Xia (2009) & Math & 0.058 & 0.058 & I & 1 \\
\hline 7 Yuhong Du, Yongmei Hu (2009a) & Math & 0.001 & 0.219 & 0.096 & -0.263 \\
\hline 8 Yuhong Du, Yongmei Hu (2009b) & Chinese & 0.101 & 0.222 & 0.239 & -0.158 \\
\hline 9 Haiping Xue, Weifang Min (2008a) & Math & 0.126 & 0.17 & 1 & 0.123 \\
\hline 10 Haiping Xue, Weifang Min (2008b) & Chinese & 0.104 & 0.066 & l & 0.145 \\
\hline 11 Yongmei Hu (2007a) & Math & 0.114 & l & 0.106 & 0.122 \\
\hline 12 Yongmei Hu (2007b) & Chinese & 0.143 & l & 0.096 & 0.144 \\
\hline 13 Yongmei Hu (2007c) & Math & 0.231 & 0.232 & 0.204 & 1 \\
\hline 14 Yongmei Hu (2007d) & Chinese & 0.181 & 0.19 & 0.193 & 0.178 \\
\hline $\begin{array}{l}\text { Xuehui An, Emily Hannum, } \\
\text { Tanja Sargent (2008) }\end{array}$ & Total & -0.0021 & -0.0021 & l & l \\
\hline 16 Jennifer Adams (2012) & Math & 0.085 & 0.053 & I & l \\
\hline 17 Qiuyi Weng (2009) & Total & -0.219 & -0.219 & -0.052 & l \\
\hline 18 Yanqing Ding, Haiping Xue (2008) & Total & 0.081 & 0.081 & I & 0.168 \\
\hline 19 Haiping Xue, Rong Wang (2009a) & Math & 0.199 & 0.164 & I & 0.234 \\
\hline 20 Haiping Xue, Rong Wang (2009b) & Math & 0.235 & 0.143 & I & 0.322 \\
\hline
\end{tabular}

\section{Table 4. Calculation of Effect Amount.}

\begin{tabular}{|c|c|c|c|c|c|c|c|c|}
\hline & \multirow[b]{2}{*}{$\mathrm{EQ}$} & \multicolumn{2}{|c|}{$\begin{array}{l}\text { Effect Amount } \\
\text { (Point Estimate) }\end{array}$} & \multirow[b]{2}{*}{ SEM } & \multirow[b]{2}{*}{ Variance } & \multirow[b]{2}{*}{$\begin{array}{l}\text { Confidence } \\
\text { Interval }\end{array}$} & \multirow[b]{2}{*}{$\begin{array}{l}\mathrm{Z} \\
\text { Value }\end{array}$} & \multirow[b]{2}{*}{$\begin{array}{l}\mathbf{P} \\
\text { Value }\end{array}$} \\
\hline & & $\begin{array}{l}\text { Random } \\
\text { Effect }\end{array}$ & $\begin{array}{l}\text { Fixed } \\
\text { Effect }\end{array}$ & & & & & \\
\hline $\begin{array}{l}\text { Overall } \\
\text { Impact }\end{array}$ & 20 & 0.093 & 0.089 & 0.027 & 0.01 & [0.039-0.147] & 3.393 & 0.001 \\
\hline $\begin{array}{l}\text { Human } \\
\text { Resources }\end{array}$ & 18 & 0.121 & 0.060 & 0.020 & 0.00 & [0.082-0.161] & 5.972 & 0.000 \\
\hline $\begin{array}{l}\text { Financial } \\
\text { Resources }\end{array}$ & 12 & 0.120 & 0.105 & 0.049 & 0.002 & [0.024-0.215] & 2.458 & 0.014 \\
\hline $\begin{array}{l}\text { Material } \\
\text { Resources }\end{array}$ & 12 & 0.099 & 0.103 & 0.038 & 0.001 & {$[-0.025-0.173]$} & 2.629 & 0.009 \\
\hline
\end{tabular}


Table 5. Calculation of the Effect Amount of Each Sub-Variable of Human Resources.

\begin{tabular}{|c|c|c|c|c|c|c|c|c|}
\hline \multirow{2}{*}{$\begin{array}{l}\text { Human } \\
\text { Resources } \\
\text { Variables }\end{array}$} & \multirow[b]{2}{*}{$E Q$} & \multicolumn{2}{|c|}{$\begin{array}{l}\text { Effect Amount } \\
\text { (Point Estimate) }\end{array}$} & \multirow[b]{2}{*}{ SEM } & \multirow[b]{2}{*}{ Variance } & \multirow[b]{2}{*}{$\begin{array}{l}\text { Confidence } \\
\text { Interval }\end{array}$} & \multirow[b]{2}{*}{$\begin{array}{l}\text { Z } \\
\text { Value }\end{array}$} & \multirow[b]{2}{*}{$\begin{array}{l}\text { P } \\
\text { Value }\end{array}$} \\
\hline & & $\begin{array}{l}\text { Random } \\
\text { Effect }\end{array}$ & $\begin{array}{l}\text { Fixed } \\
\text { Effect }\end{array}$ & & & & & \\
\hline $\begin{array}{l}\text { Teacher } \\
\text { Experience }\end{array}$ & 8 & 0.185 & 0.177 & 0.059 & 0.003 & {$[0.069,0.301]$} & 3.315 & 0.002 \\
\hline $\begin{array}{l}\text { Teacher } \\
\text { Training }\end{array}$ & 3 & 0.137 & 0.145 & 0.038 & 0.001 & {$[0.062,0.211]$} & 3.607 & 0.000 \\
\hline $\begin{array}{l}\text { Teacher } \\
\text { Education }\end{array}$ & 8 & 0.144 & 0.160 & 0.023 & 0.001 & {$[0.099,0.188]$} & 6.292 & 0.000 \\
\hline $\begin{array}{l}\text { Teacher } \\
\text { Title }\end{array}$ & 8 & 0.101 & 0.081 & 0.025 & 0.001 & {$[0.052,0.151]$} & 3.996 & 0.000 \\
\hline $\begin{array}{l}\text { Teacher } \\
\text { Qualifications }\end{array}$ & 11 & 0.134 & 0.109 & 0.030 & 0.001 & {$[0.075,0.193]$} & 4.478 & 0.000 \\
\hline $\begin{array}{l}\text { Student- } \\
\text { Teacher Ratio }\end{array}$ & 6 & 0.150 & 0.154 & 0.032 & 0.001 & {$[0.089,0.212]$} & 4.763 & 0.000 \\
\hline $\begin{array}{l}\text { Teacher- } \\
\text { Student Ratio }\end{array}$ & 3 & 0.263 & 0.015 & 0.196 & 0.038 & {$[-0.120,0.647]$} & 1.346 & 0.178 \\
\hline
\end{tabular}

\begin{tabular}{|c|c|c|c|c|c|c|c|c|}
\hline \multirow{2}{*}{$\begin{array}{l}\text { Material } \\
\text { Resource } \\
\text { Variables }\end{array}$} & \multirow[b]{2}{*}{$E Q$} & \multicolumn{2}{|c|}{$\begin{array}{l}\text { Effect Amount (Point } \\
\text { Estimate) }\end{array}$} & \multirow[b]{2}{*}{ SEM } & \multirow[b]{2}{*}{ Variance } & \multirow[b]{2}{*}{$\begin{array}{l}\text { Confidence } \\
\text { Interval }\end{array}$} & \multirow[b]{2}{*}{$\begin{array}{l}\text { Z } \\
\text { Value }\end{array}$} & \multirow[b]{2}{*}{$\begin{array}{l}\mathbf{P} \\
\text { Value }\end{array}$} \\
\hline & & $\begin{array}{l}\text { Random } \\
\text { Effect }\end{array}$ & $\begin{array}{l}\text { Fixed } \\
\text { Effect }\end{array}$ & & & & & \\
\hline $\begin{array}{l}\text { Computer } \\
\text { Networking } \\
\text { Rate }\end{array}$ & 3 & 0.032 & 0.032 & 0.006 & 0.000 & {$[0.020,0.043]$} & 5.307 & 0.000 \\
\hline $\begin{array}{l}\text { Number of } \\
\text { Computers } \\
\text { Per Student }\end{array}$ & 3 & -0.012 & -0.012 & 0.008 & 0.000 & {$[-0.027,0.002]$} & -1.659 & 0.097 \\
\hline $\begin{array}{l}\text { Per Capita } \\
\text { Fixed As- } \\
\text { sets }\end{array}$ & 2 & 0.238 & 0.238 & 0.103 & 0.011 & {$[0.037,0.439]$} & 2.325 & 0.020 \\
\hline $\begin{array}{l}\text { Construction } \\
\text { Area Per } \\
\text { Student }\end{array}$ & 1 & -0.052 & -0.052 & 0.033 & 0.111 & {$[-0.704,0.600]$} & -0.156 & 0.876 \\
\hline $\begin{array}{l}\text { Classroom } \\
\text { Area Per } \\
\text { Student }\end{array}$ & 4 & 0.112 & 0.106 & 0.045 & 0.002 & {$[0.201,2.485]$} & 2.485 & 0.000 \\
\hline $\begin{array}{l}\text { Number of } \\
\text { Books Per } \\
\text { Student }\end{array}$ & 5 & -0.106 & -0.040 & 0.173 & 0.030 & {$[-0.445,0.234]$} & -0.610 & 0.542 \\
\hline $\begin{array}{l}\text { Area Per } \\
\text { Student }\end{array}$ & 4 & 0.222 & 0.265 & 0.048 & 0.002 & {$[0.129,0.315]$} & 4.664 & 0.000 \\
\hline
\end{tabular}


not large, so this result needs to be treated with caution.

\section{Regulatory Effect Analysis}

According to the above analysis, it is known that heterogeneity exists between samples, and the source of heterogeneity is not caused solely by sampling errors. This paper explores possible sources of heterogeneity through the analysis of regulatory effects. In the meta-analysis literature related to student learning outcomes, moderating variables are usually selected from research disciplines, research stages, and research areas (Gu \& $\mathrm{Hu}, 2018$; Zheng, et al. 2018; Wang \& Hu, 2018). Zhang et al. proposed that subgroup analysis can also be divided from professional perspectives such as research quality, design schemes, and statistical perspectives (Zhang, et al., 2015), and the principles of subgroup analysis and adjusted variable analysis are similar, so this perspective can also Select the manipulated variable. Therefore, this paper selects seven variables as research subject, research area, research period, research design, research method, document type and data type as moderator variables. Because the results of the analysis of the adjustment effects of human resources input, material resources input, and financial resources effects of the school are consistent with the overall analysis results, they are limited in space and only report the analysis results of the overall adjustment effects (see Table 7).

From the results in Table 7, it can be seen that the research subject $(\mathrm{QB}=$ $36.128, \mathrm{p}<0.001)$, the research area $(\mathrm{QB}=9.762, \mathrm{p}=0.045)$, and the data type $(\mathrm{QB}=$ $11.604, \mathrm{P}=0.003$ ) are the main reasons for the difference in the effect amount. There is a significant difference in the amount of effect between different disciplines. The impact of school resource investment on Chinese and mathematics is significant, and the amount of effect is 0.171 and 0.123 , respectively. It shows that the school's investment in resources will increase by one standard deviation. Students 'language performance will increase by 0.171 standard deviations, and students' mathematics performance will increase by 0.123 standard deviations. Different regional effects are not the same, but except for the eastern region, the effect amount is not significant. The effect amount of the results of studies conducted in the central region and the eastern part of the country, and in the central and eastern parts of the country, shows a positive and significant effect with the range of $[0.081,0.193]$.

\section{Robustness Test}

After calculating the research results, further publication bias testing and sensitivity analysis are needed to ensure the reliability of the research results. Publication bias means that statistically significant positive research results are easier to publish than statistically insignificant negative research results. If there is a publication bias, the combined effect amount will be greater than the actual effect amount, so the combined effect amount calculated in the fifth step needs to be corrected. There are usually two types of publication bias testing methods: the funnel graph method and the Egger test. The former determines whether there is a publication bias by checking whether the fun- 


\begin{tabular}{|c|c|c|c|c|c|c|}
\hline Manipulate & Variable (Coding) & $\mathrm{K}$ & $\mathbf{Q}_{\mathrm{B}}$ & ES & $95 \% \mathrm{Cl}$ & $\mathbf{P}$ \\
\hline \multirow{5}{*}{$\begin{array}{l}\text { Output } \\
\text { Variable } \\
\text { (Output) }\end{array}$} & Chinese & 5 & \multirow{5}{*}{$\begin{array}{l}36.128 \\
(p<0.0001)\end{array}$} & 0.171 & $0.126-0.216$ & $<0.001$ \\
\hline & Mathematics & 10 & & 0.123 & $0.080-0.166$ & $<0.001$ \\
\hline & Science & 1 & & 0.023 & $-0.016-0.062$ & 0.250 \\
\hline & Reading & 1 & & 0.009 & $-0.044-0.062$ & 0.739 \\
\hline & Total & 2 & & -0.048 & $-0.238-0.143$ & 0.625 \\
\hline \multirow{5}{*}{$\begin{array}{l}\text { Study Area } \\
\text { (Aera) }\end{array}$} & Nationwide $(\mathrm{N})$ & 1 & \multirow{5}{*}{$\begin{array}{l}9.762 \\
(p=0.045)\end{array}$} & 0.081 & $0.030-0.132$ & 0.002 \\
\hline & Central $(\mathrm{M})$ & 2 & & 0.193 & $0.075-0.310$ & 0.001 \\
\hline & West (W) & 9 & & 0.115 & $0.069-0.160$ & $<0.001$ \\
\hline & Central and Eastern (EM) & 4 & & 0.149 & $0.100-0.198$ & $<0.001$ \\
\hline & East (E) & 4 & & -0.043 & $-0.187-0.102$ & 0.563 \\
\hline \multirow{3}{*}{$\begin{array}{l}\text { Research } \\
\text { Section } \\
\text { (Grade) }\end{array}$} & Elementary School $(\mathrm{P})$ & 8 & \multirow{3}{*}{$\begin{array}{l}1.365 \\
(p=0.505)\end{array}$} & 0.118 & $0.073-0.164$ & $<0.001$ \\
\hline & Middle School (S) & 11 & & 0.074 & $-0.038-0.86$ & 0.194 \\
\hline & High School $(\mathrm{H})$ & 1 & & 0.081 & $0.030-0.132$ & 0.002 \\
\hline \multirow{2}{*}{$\begin{array}{l}\text { Research } \\
\text { Design } \\
\text { (Study } \\
\text { Design) }\end{array}$} & $\begin{array}{l}\text { Quasi-Longitudinal } \\
\text { Research (QL) }\end{array}$ & 12 & \multirow{2}{*}{$\begin{array}{l}2.551 \\
(p=0.110)\end{array}$} & 0.133 & $0.096-0.171$ & $<0.001$ \\
\hline & $\begin{array}{l}\text { Non-longitudinal research } \\
\text { (FL) }\end{array}$ & 8 & & 0.042 & $-0.065-0.148$ & 0.444 \\
\hline \multirow{2}{*}{$\begin{array}{l}\text { Research } \\
\text { Method } \\
\text { (Method) }\end{array}$} & HLM & 17 & \multirow{2}{*}{$\begin{array}{l}2.363 \\
(p=0.124)\end{array}$} & 0.113 & $0.078-0.147$ & $<0.001$ \\
\hline & OLS & 3 & & -0.077 & $-0.316-0.162$ & 0.529 \\
\hline \multirow{2}{*}{$\begin{array}{l}\text { Literature } \\
\text { Type } \\
\text { (Lt) }\end{array}$} & Papers $(\mathrm{J})$ & 15 & \multirow{2}{*}{$\begin{array}{l}1.949 \\
(p=0.163)\end{array}$} & 0.074 & $-0.009-0.158$ & 0.080 \\
\hline & Non-Journal Papers (non-J) & 5 & & 0.144 & $0.093-0.195$ & $<0.001$ \\
\hline \multirow{3}{*}{$\begin{array}{l}\text { Data } \\
\text { Sources }\end{array}$} & International data $(\mathrm{G})$ & 3 & \multirow{3}{*}{$\begin{array}{l}11.604 \\
(P=0.003)\end{array}$} & 0.019 & $-0.01-0.047$ & 0.209 \\
\hline & $\begin{array}{l}\text { Large domestic monitoring } \\
\text { data (C) }\end{array}$ & 15 & & 0.097 & $0.033-0.161$ & 0.003 \\
\hline & Self-made experimental data (I) & 2 & & 0.193 & $0.075-0.310$ & 0.001 \\
\hline
\end{tabular}

nel graph is symmetrical, and the latter quantifies the publication bias by intercept. The funnel chart of the overall impact of school resources input on student performance is shown in Figure 3. The chart is approximately symmetrical, so there may be no publication bias, but to ensure the accuracy of the test, an Egger test is also required. Egger's test results also showed that there was no publication bias for this meta-analysis result $(\mathrm{B} 0=0.043, \mathrm{t}=0.016, \mathrm{p} 1=0.494, \mathrm{p} 2=0.987)$.

Sensitivity analysis refers to whether the results change with the analysis conditions (Xia, 2005). The fail-safe $\mathrm{N}$ method is usually used to judge the possibility of publication bias to change the meta-analysis conclusion (Zeng \& Yao, 2018). The larger $\mathrm{N}$ is, the more studies need to be included and the more stable the results. Generally, it is necessary to increase the sample size to be $5 \mathrm{k}+10$ or more of the existing sample size to determine that the result is stable (Rosenthal, 1979). The coefficient of insecurity 
Figure 3. Funnel Chart of the Impact of School Resource Input on Student Performance.

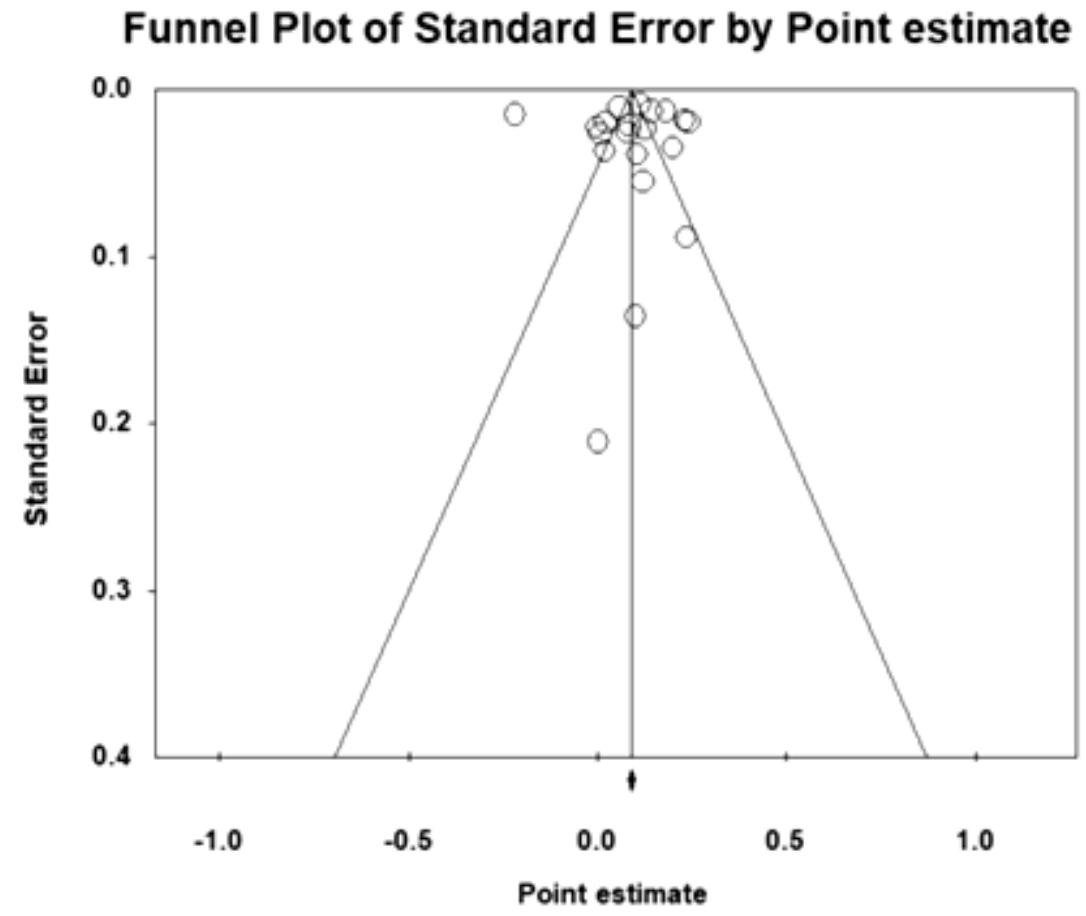

calculated in this study is $\mathrm{N}=1,676(\alpha=0.050, \mathrm{p}<0.0001)$, so the conclusion can be proved to be robust.

\section{Discussion}

\section{School Resource Investment Significantly Impacts Stu- dent Performance}

The effect amount of school resources on student performance is 0.093 . Since the standard regression coefficient is used as the effect amount in this study, an increase of one standard deviation in school resource investment will increase student performance by 0.093 standard points. It can be seen that the impact of school resources on student performance is very significant. The results of this study are consistent with the results of Greenwald et al. regarding 60 studies from the USA, but the results are slightly larger than those of Greenwald et al. This shows that the effect of Chinese school resource investment may be greater than that of the United States, and it also shows that the Chi- 
nese school resource investment is relatively insufficient, and the marginal efficiency of resource investment is still at the marginal increasing stage, and it has not reached the optimal input level.

\section{The School's Investment in Human, Financial and Mate- rial Resources Significantly Affects Student Performance, and Human Resources are More Effective}

This study finds that different resources invested in schools have different effects on students. Among them, the school's human resources investment has the best effect, with an effect amount of 0.121 . An in-depth analysis of the impact of various variables on school human resources input found that teacher experience, teacher education, teacher qualifications, teacher training, teacher titles, and student-teacher ratios all have a positive and significant impact on student performance. The research results are consistent, and they all conclude that teachers are the most important factor affecting student performance (Hedges, et al., 1994; Hattie, 2015).

Teachers have always been considered to be an important factor affecting student performance. Nye et al. found that nearly 7\%-12\% of differences in student performance are caused by teachers (Nye, et al., 2004). Rowe et al. studied that only schools with effective teachers can be called effective schools (Rowe \& Rowe, 1993). In addition, Hattie, through a meta-analysis of more than 800 students' academic achievements, obtained "teachers" as the main reason for education excellence, and praised teachers as the "holy grail of teaching" (Hattie, 2015). However, the teachers that Hattie refers to are not just teachers 'human capital factors such as their education, qualifications, and experience, but more influences on teachers' teaching, such as teaching strategies and teacher-student relations. Therefore, after drawing the conclusion that teacher resources investment, especially teacher experience, teacher qualifications, teacher qualifications, teacher training, teacher titles, student-teacher ratios have a positive impact on student performance, further research on its impact mechanism, namely teacher human capital, is needed. How do you influence student performance? In the current research on the relationship between teacher human capital and student achievement, more attention is paid to whether it has an impact, the degree of influence and direction, and less attention to whether its impact mechanism is through the influence of teacher human capital on teacher teaching style and student performance, or through teaching. Strategies to influence student achievement, or to achieve impact through other means need further exploration in the future.

The second is financial resources. In the past meta-analysis of investment in education funding, it was considered that the impact of education funding on student performance was small. How to use is more important than the amount of funds (Hanushek, 1989; Hanushek, 2003). Rolle also reached this conclusion, arguing that a large amount of investment is not necessary, and more importantly, how to use existing resources more efficiently (Rolle, 2004). In contrast, a series of studies by Hedges et al. found that educational investment has a positive and systematic impact on student per- 
formance, and thus refutes the view that financial investment has only a limited impact on student performance (Hedges, et al., 1994; Hattie, 2015). Our results are roughly consistent with the results of Hedges, which found that the investment of school financial resources has a positive and significant impact on student performance. However, in our research, the impact of financial resources input on student performance is not inferior to human resources, with an effect amount of 0.120 , which is only 0.001 lower than the effect amount of human resource investment. This is slightly different from the conclusion that Hedges et al found that teachers are more important. The reasons may be caused by the selected variables and samples, or they may be caused by different national conditions between China and the United States.

The last is the investment of material resources, with a standardization coefficient of 0.099 , which is less than the effect of the school's financial and human resources, but the impact cannot be underestimated. In the analysis of input of different material resources, computer networking rate, fixed assets per student, classroom area per student, and school area per student significantly affect student performance.

\section{The Effect of School Resource investment Varies by Sub- ject, Region, and Data Type}

From the results of the adjustment effect, it can be found that the effect of school resource investment varies in different disciplines and regions. Among them, the subject of Chinese language and mathematics is more susceptible to impact, while the impact on other subjects is not significant. There may be two reasons for this research result: first, the difference caused by the uneven sample size; second, in China, Chinese language and mathematics are considered basic subjects, and they often get more education and teaching resources. Therefore, the impact of changes in school resources input on mathematics and Chinese subjects is more obvious.

The effect of school resource investment in different regions is also different, and the effect is better in the western region. The reason may be that, in addition to the uneven sample size, compared with the eastern region, China's central and western regions have a slightly lower level of economic development and insufficient economic strength. In particular, the western region has a weak economic foundation and limited investment in school resources. In this case, a slight increase in school resource investment in the central and western regions may produce better results, that is, the marginal efficiency of school resource investment is higher than in the east. For example, Ling used the data envelopment method to evaluate the efficiency of China's urban education financial expenditure, and found that there is a problem of pure technical inefficiency in urban education in China, and the pure technical efficiency of the eastern region is lower than that of the central and western regions. This shows that although the eastern region is rich in resources, the utilization efficiency of educational financial resources is not high and needs to be further improved (Ling, 2015). In recent years, China's investment in school resources in the central and western regions has increased significantly. The growth rate of financial education funding is significantly higher than that 
in the eastern regions, especially in the poor regions (Yu, 2019). Therefore, we ask whether the efficiency of school resource utilization is affected by the economic level of the school's location, whether the education input has a "ceiling effect", and the optimal input level should be an explanation, etc. All these need to be studied further.

Different data sources have different effects on the investment of educational resources. The effect of international data is the smallest, and the effect of self-edited data is the highest. This result may be related to the rigor and representativeness of data compilation. There is a possibility that the self-edited data is not as rigorous as the international data and large domestic data, resulting in a high effect amount.

\section{Conclusion and Perspective}

\section{Conclusion and Inspiration}

This study used meta-analysis to analyze 11 literatures on the impact of Chinese school resource investment on student performance, a total of 20 effect quantities. The research results found that: (1) The overall impact of school resources on student performance is significant (the effect amount is $0.093, \mathrm{p}=0.001$ ), especially in master thesis and doctoral dissertation. (2) Compared with material resources, school human resources the input effect is even better, with affect amounts of 0.121 and 0.120 respectively. The effect of material resource investment is the lowest, but the impact is also very important. The effect amount is 0.099. (3) In human resources input, teacher experience, teacher education, teacher qualification, and teacher training, teacher title, and studentteacher ratio all have a positive and significant impact on student performance; among the material resources, computer networking rates, fixed assets per student, classroom area per student, and school area per student significantly affect student performance. (4) From a disciplinary perspective, the impact of school resource investment on Chinese and mathematics is more significant, and from a regional perspective, the impact on central and western regions is more significant.

Based on the analysis above, we believe that the input of human, material and financial resources in schools can promote the improvement of student performance. China's current investment in school resources is inadequate in terms of human, material and financial resources. It is necessary to continue to increase, and in the face of effective educational resources, we should consider how to allocate these resources more effectively in order to make the development of education better, faster and more balanced. For each school, in the face of limited educational resources, we should consider how to make more effective use of these resources, and how to make internal school deployment more effective. Therefore, we believe that China still needs to increase investment in school resources, especially increase financial resources and investment in schools in the central and western regions. At the same time, it is necessary to strengthen the input and allocation of teacher resources, and effectively improve the treatment of teachers. At the same time, increase teacher training, increase investment in teacher resources in weak schools and regions, and build a more reasonable and sufficient and efficient teacher team. On this basis, we should further strengthen the research on edu- 
cation input and output, better grasp the laws, and improve the efficiency of resource utilization through scientific decision-making, and better promote student development.

\section{Perspective}

Because China does not currently have a unified measurement tool for student performance, it is difficult to obtain uniform and nationally comparable student performance data. And the complexity of school-level input data also makes it difficult for researchers to obtain this part of the data. Therefore, in this study, the comparability between results needs to be further discussed. Although they have been standardized, different measurement tools and different processing methods may still affect the results. In addition, due to the late start of quantitative research in the Chinese education industry and the existence of non-standard reports, the number of studies that can be included and the number of effect sizes are small. Therefore, the results of this study need more research for further verification.

Acknowledgement: The authors thank the anonymous reviewers for their comments and suggestions. This article was selected for the Fifth National Educational Empirical Research Forum sponsored by East China Normal University of China in 2019 and made a keynote speech. The authors thank their colleagues for their constructive suggestion.

\section{References}

Borenstein, M., Hedges, L.V., Higgins, J.P.T., \& Rothstein, H.R. (2009) Introduction to metaanalysis. New Jersey: John Wiley \& Sons:28-29

Coleman, J.S., et al. (1966) Equality of educational opportunity. Report prepared for the US Office of Education. US Government Printing Office, Washington, DC.

Ferguson, C.J. (2009) An effect size primer: A guide for clinicians and researchers. Profe Psychol: Res Prac, 40(5):532-538.

Fuller, B. (1987) What school factors raise achievement in the third world? Rev Edu Res, 57(3):255-292.

Glass, G.V. (1976) Primary, secondary, and meta-analysis of research. Edu Res, 6(5):3-8.

Gu, X.Q., Hu, M.H. (2018) Has the learning effect of electronic schoolbags happened? A meta-analysis based on 39 papers at home and abroad. Tel Edu Res, 5:19-25.

Hanushek, E.A. (1989) The impact of differential expenditures on school performance. Edu Res, 18(4):45-65.

Hanushek, E.A. (1995) Interpreting recent research on schooling in developing countries. World Bank Res Obse 10(2):227-246.

Hanushek, E.A. (1997) Assessing the effects of school resource on student performance: An update. Edu Eva Policy Anal, 19(2) (Summer):141-164.

Hanushek, E.A. (2003) The failure of inputbased schooling policies. Econ J, 113(485):64-98.

Hedges, L.V., Richard, D., Laine, R.D., Greenwald, R. (1994) Does money matter? A meta -analysis of studies of the effects of differen- 
tial school inputs on student outcomes. Edu Res, 23(3):5-14.

Hu, Y.M., (2007) A study on the relationship between school resource allocation and students' academic achievements: Based on an empirical analysis of rural primary and middle schools in five provinces of the west. Beijing: Beijing Nor Univ, 8 .

Jiang, M.H. (2000) Analysis of education costs. High Edu Press, pp79-pp81.

John, H. (2015) Visible learning: A comprehensive report on over 800 meta-analyses of academic achievements. Beijing: Edu Sci Press. Translated by Peng, Z.M., et al.

Li, X.Y., Zhang, J.S. (2018) The impact of public education investment on school education results: an empirical study based on data from 70 elementary schools in Hubei Province. J Zhongnan Univ Econ Law, 6:81-88.

Ling, Y.D. (2015) Evaluation on the efficiency of urban education fiscal expenditure in China. Finac Superv, 2:34-38.

Lipsey, M.W., Wilson, D.B. (2001) Practical meta-analysis. Sage Publications, Inc.: pp31.

Lu, X.F., Tang, Y.H., Zeng, F.M. (2011) Effect amount: estimation, reporting and interpretation, Explo Psychol, 31(3):260-264.

Mark W. Lipsey David B. Wilson. (2001). PRACTICAL METAANALYSIS, Applied Social Research Methods Series Volume 49: pp67

Nye, C., Foster, S.H., and Hedges, L.V. (2004). How large are teacher effects? Educational Evaluation and Policy Analysis, 26(3):237257.

Pentti, N., Heli, L., Antti, H. (2013) Standardised regression coefficient as an effect size index in summarizing findings in epidemiological studies, Epid Biostat Pub Hlth, 10(4): e8854-1-e8854-15.

Rob, G., Larry, V.H., Richard, D.L. (1996) The effect of school resources on student achievement. Rev Edu Res, 66(3):361-396.

Rolle, A. (2004) Out with the old-in with the new: Thoughts on the future of educational productivity research. Pea J Edu, 79(3):3156.

Rosenthal, R. (1979) The "file drawer problem" and tolerance for null results. Psychol Bull, 86:638-641.

Rowe, K.J., Rowe, K.S. (1993) Assessing student behaviour: the utility and measurement properties of a simple parent and teacheraalian. Assoc Res Edu, Fremantle, WA.

Rücker, G., Schwarzer, G., Carpenter, J.R. et al. (2008) Undue reliance on I2 in assessing heterogeneity may mislead. BMC Med Res Method, 8 (1):79.

Wang, C.R., Hu, Y.B. (2018) Can flipping the classroom really improve academic performance? A meta-analysis based on 38 experimental and quasi-experimental studies, Open Edu Res, 24(4):72-80.

Xia, L.X. (2005) Meta-analysis and its application in social science research. J NWU (Soc Sci Edit), 42(5):55-58.

Yu, X. (2019) Funding for general senior high school education in poor areas of central and western China: Achievements, problems and countermeasures, J Edu, 15(3):94-103.

Zeng, Z.B., Yao, J.J. (2018) Finding the "best evidence": How to use meta-analysis to conduct literature review: Taking the study of the impact of STEM education on student achievement as an example. Selected Essays of "The Fourth Empirical Forum on Education” of East China Normal University, 2018.

Zhang, T.S., Dong, S.J., Zhou, Z.R. (2015) Advanced meta-analysis method: Based on Stata. Shanghai: Fudan Univ Press.

Zhao, B.H. (2013). Analysis of family and school factors affecting students' academic achievements. Edu Res, 3:88-97.

Zheng, L.Q., Cui, P.P., Li, X. (2018) Can mobile learning promote learning performance: A meta-analysis based on 92 studies of international English Journals in 2011-2017. Modern Dist Edu, 6:45-54. 